\title{
Multilingual Behaviour within the Portuguese and Italian Communities in Montreal: A Quest of Purism
}

Fabio Scetti

Citation: Scetti, Fabio. 2021.

Multilingual Behaviour within the Portuguese and Italian Communities in Montreal: A Quest of Purism. Languages 6: 91. https://doi.org/ 10.3390/languages6020091

Academic Editors: Jaine Beswick and Darren Paffey

Received: 4 February 2021

Accepted: 13 May 2021

Published: 18 May 2021

Publisher's Note: MDPI stays neutral with regard to jurisdictional claims in published maps and institutional affiliations.

Copyright: (C) 2021 by the author. Licensee MDPI, Basel, Switzerland. This article is an open access article distributed under the terms and conditions of the Creative Commons Attribution (CC BY) license (https:// creativecommons.org/licenses/by/ $4.0 /)$.
Dipralang, Université Paul-Valéry Montpellier 3, 34199 Montpellier, France; fabio.scetti@univ-montp3.fr

\begin{abstract}
Many heritage speakers, starting particularly from the second generation, return to the practice of their heritage languages so as to build or rebuild their diasporic and heritage identities. Within an urban context such as in Montreal (Quebec), multilingual behaviour exists. This is due to the presence of multiple languages and dialects, as well as the bilingual reality of this city, where both French and English are dominant. Such conditions provide evidence of how determinant in-group ideologies and stereotypical attitudes are concerned with communities and languages (standard and vernacular) and how they function in the process of linguistic integration within the group and the Canadian city. Focusing on recent research that compares heritage speakers of Portuguese and Italian origin in Montreal, this contribution addresses whether identifying places have an important role in the process of integration within the group, in shared spaces of language or dialect practice, both private and public. Moreover, questions arise as to how standard languages are valued within both communities (mainly in schools) and how competency and legitimacy have been evaluated and by whom, in this process of integration. The two communities observed are very different, given the practice and behaviour as well as in-group ideologies of inclusion. This contribution argues that, as a consequence of our 'global' societies, there is an extension of new identities during the process of development where multilingual behaviour is reviewed and analysed for the dynamicity in the repertories of new generation speakers. Our comparison brings to light a central ideology of language purism, and the ways in which it is institutionalized and/or contested across the two groups.
\end{abstract}

Keywords: Italian and Portuguese migration; Montreal; identity practices; ideologies of purism; multilingualism

\section{Introduction}

During the 19th and 20th centuries, the city of Montreal, Quebec, was the Canadian 'open door' to the world, in particular to migrant families crossing the Atlantic Ocean from Europe. Migrants who came by boat, after docking at Pier $21^{1}$ in Halifax, Nova Scotia, could actually reach Montreal by train before being dispatched to other cities and regions of the country. Since the 1960s, given that migrants could fly directly to the city's airport, Pier 21 closed definitively in 1971. Many of these migrants, often known as 'birds of passage' (Pretelli 2011), initially arrived in Montreal, eager to seek their fortune, freedom, new opportunities, land and, over time, gradually settle there. Montreal was the place where seasonal workers returned to in order to find another job and place to work. For that reason, these previously sojourning migrants gradually settled in a city that for much of the 20th century was the industrial and commercial centre of Canada (Linteau 2000).

The 'new home' of the first migrants is today a city with a population of around 4 million people, according to its urban agglomeration RMM $^{2}$ (Statistics Canada 2016),

1 Pier 21-Created in 1924, the new platform 21, named Transit Shed 21, was inaugurated to accommodate the largest number of migrants coming from Europe. Closed in 1971, it became a museum in 1991-Canadian Museum of Immigration at Pier 21: [http:/ /www.pier21.ca] (accessed on 19 December 2020).

2 RMM-Région Métropolitaine de Montréal (Greater Montreal Area). 
representing half of the population of the entire province of Quebec. All these people have contributed to building this city's multiple-faceted identity-a puzzle of different colours, where diverse languages and dialects cohabitate and are spoken daily; one of the reasons why Montreal was ranked as one of the most liveable cities in the world. ${ }^{3}$

Within the linguistic landscape of Montreal where the two languages of French and English are dominant, other multiple languages and dialects share spaces, in the private sphere of the home, as well as the public sphere, within the so-called 'ethnic enclaves' (Zucchi 2007). A completely noteworthy reality can be experienced by taking a stroll around the city, from the Saint Lawrence River up to the Mont-Royal following the 'Main', Saint Lawrence Boulevard, starting from Chinatown near the old town to Little Portugal, crossing the Mile-End-noted particularly for the Hasidic Jewish community that resides there-reaching Little Italy and, further along, the Greek area of Parc-Extension. There were and still are other 'ethnic enclaves' within the city as well as in other areas inhabited by people from different origins (Germain 1999). One such enclave worth noting is the Irish ward of Saint-Ann. The presence of both Ukrainian and Polish communities is visible too, in the vicinity of Saint Sophie Ukrainian Orthodox Cathedral in Rosemont and the Catholic Church of St. Michael and St. Anthony in Mile-End. More recently: the Lebanese borough of Saint-Laurent, also named 'Saint-Liban' (Saint Lebanon) in French; the Haitian district in Villeray; the 'Petit-Maghreb' in Saint-Michel, and the South American presence in La Petite-Patrie.

This study is primarily concentrated on two groups: the Portuguese and Italian communities. Based on recent research carried out by the author, both communities are compared for similarities and divergences, with a particular focus on language practice and behaviour. Insight is provided into the complex issue of building ideologies among members of the same group: ideologies of inclusion within the city of Montreal and the in-group, as well as within the community. Standard Italian and standard European Portuguese may be regarded today as two flags towering over each community and their neighbourhoods. Nonetheless, the process of controlling and dominating these spaces has been different and has not yet been completed. Consequently, questions arise as to how these two languages are spoken today, where, in which situation, by whom, by what age group and why they are still spoken.

Both communities, different in relation to their history, still have many points in common with regard to language practices as well as representations of their group inside Montreal. In our global society, where individuals may experiment a crisis of identity, multilingual behaviour is reviewed and analysed for its dynamicity, reconsidering new multilingual repertories and new indefinite identities. In Montreal, a context where multilingualism is observed (see: Magnan and Lamarre 2016; Sarkar and Low 2012; Das 2008; Park and Sarkar 2007; and Heller 2007), in-group ideologies and stereotypical attitudes are determinant in order to maintain a strong sense of community within urban reality.

\section{Context: Montreal, a City with Multiple Faces}

Montreal was retained for the purpose of this study for the reasons that the city has the characteristic of being 'divided' and the focus of this study was based on an urban area. Montreal is seen as divided given the presence of the two dominant languages of French and English ${ }^{4}$, in a context of a 'double majority' where French is the most widely spoken language, and English maintains its status of an international and business language (Anctil 1984). In addition, the city can also be seen as divided in respect to local political ideologies - the francophone interculturalism of the province of Quebec on the one hand, and the federal multiculturalism of Canada, on the other.

3 The Global Liveability Ranking is an annual publication of the Economist Intelligence Unit (EIU)—[www.eiu.com] (accessed on 19 December 2020).

4 The city is not officially bilingual, although its residents consider it to be. A survey conducted in 2013 by CBC/Radio Canada showed that $77 \%$ of the inhabitants consider the city to be bilingual: [http://www.cbc.ca/news/canada/montreal/majority-of-montreal-residents-see-city-as-bilingualpoll-1.2100712] (accessed on 19 December 2020). 
In this 'city with two faces' (Scetti 2019), different communities live in a multicultural reality in which the linguistic debate is often present in society. Talking about language and languages is a recurring theme that animates citizens. The languages of allophones, other than French and English, share the same space and redefine their limits, giving multiple faces to the city.

\subsection{The Portuguese Community of Montreal}

Portugal and Canada established a controlled immigration project during 1950s (see: Teixeira and Da Rosa 2009). In fact, in 1951, the Junta da Emigração (emigration board) which controlled the migratory flows from Portugal, contacted the Portuguese Consulate in Montreal to define a stable plan. Canada agreed to receive a pilot group in 1953, the 'pioneers' of the Portuguese migration in the country (Moura and Soares 2003).

From the following year, many Portuguese, mostly from the Portuguese islands of the Azores, arrived by boat in Halifax and continued on to Montreal before moving to other provinces of the federation. The first Portuguese community settled in Montreal, along the Saint Lawrence Boulevard, in and around the district of Saint-Louis in the borough of Plateau Mont-Royal. The majority of these immigrants were originally from the islands of the Azores and Madeira. Later, other Portuguese from the northern and central regions of Portugal arrived in the city and settled in Saint-Louis. It was often within this neighbourhood that 'mainlanders' and 'islanders' first met. As far as they were concerned, they thought they were going to 'America' and they did not even know where Canada was, and that French was a language spoken there. Today, there are many other Portuguese communities across the country such as in Toronto, Vancouver, Hamilton, Ottawa-Gatineau, London (Ontario) and Winnipeg.

At present, according to statistics from the Portuguese Consulate and the Census ${ }^{5}$ (Statistics Canada 2016), Montreal is the only city where there is a balance between 'mainlanders' and 'islanders', in a community totalling about 60,000 individuals in the Greater Montreal Area (Statistics Canada 2016). Montreal has the second largest Portuguese community, preceded by Toronto. Since the 1950s, the community has left this area, as many Portuguese relocated to the suburbs in the northern, north-eastern areas, and to the southern bank of the river (Teixeira and Da Rosa 2009).

Nonetheless, it is within the so-called comunidade (community) in Saint-Louis that the Portuguese language is used routinely in public. This district has maintained its role as the centre of the community (Figure 1). It is an area where one can stroll between restaurants, grocery shops, bars, clubs and associations from different regions of Portugal. The oldest Portuguese association in Canada, created in 1956, Associação Portuguesa do Canadá, is among them, and so is the Clube Portugal de Montreal, which was created in 1965. In this locality, people can be heard speaking Portuguese, and from their accents, it is possible to guess which area of Portugal they originated from. From an azulejo tile displayed at the entrance of a house, it is easy to guess where a Portuguese family live or used to live. Missão Santa Cruz, considered to be the main centre of the community, is located in the heart of the district. This Roman Catholic institution, built in 1984, offers religious services in Portuguese, and houses the community school founded through the merger of the Santa Cruz (primary school) and the Lusitana (secondary school). Children from 6 to 18 years of age can study the Portuguese language there, as well as Portuguese culture and history, geography and mathematics. In this school, teachers use and teach standard European Portuguese (EP), despite the fact that the Portuguese community has become a very important pied-à-terre for the integration of Brazilian immigrants, so much so that according to Almeida (2014), migrants from Brazil rely heavily on Portuguese institutions when first arriving in Montreal, not having established their own community yet.

\footnotetext{
Statistics from the Consulate take in consideration the Canadian Census and people who are registered to their lists.
} 


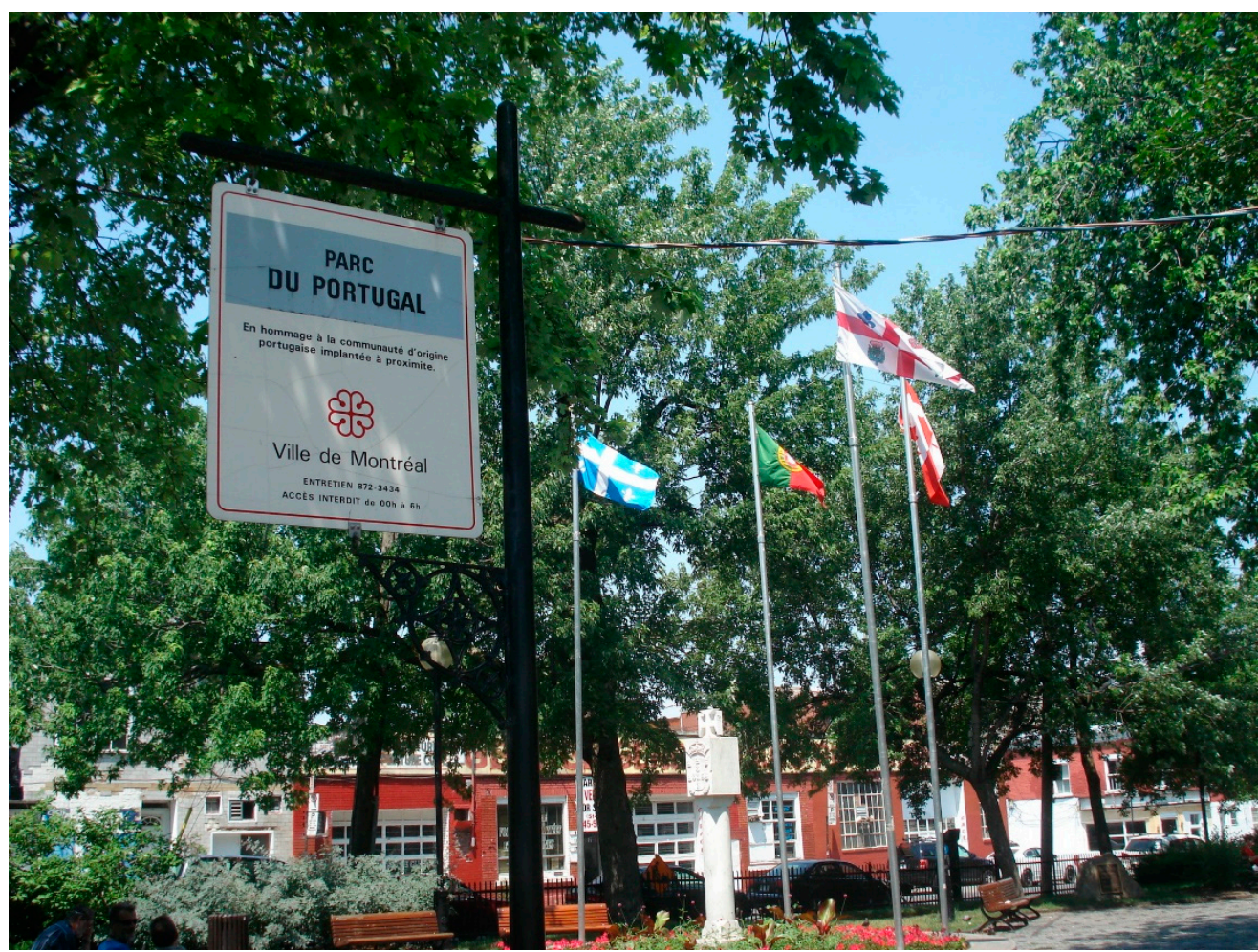

Figure 1. Parc $d u$ Portugal, Saint-Laurent/Marie-Anne. The park was dedicated to Portuguese immigrants and their community.

This fact raises the issue of the two dominant varieties of the Portuguese languagethe European (EP) and the Brazilian (BP), where other varieties, mainly from the islands, such as Insular Portuguese (IP), are not even considered (Scetti 2017). It was noted when fieldwork was being carried out between 2011 and 2018, that a new openness towards the Brazilian community had come about within the Portuguese community; in the church of Santa Cruz, beside the statue of Our Lady of Fátima stands the statue of Our Lady of Aparecida erected in 2018-a saint widely venerated by Brazilian Catholics. However, according to the school statistics, the number of students of Brazilian origin enrolled at Santa Cruz and Lusitana is still very low. This may be related to the dominance of EP and to the larger number of students of Portuguese origin. This situation is very different from the one observed in Bridgeport (Connecticut, United States of America), during fieldwork carried out in 2018 (Scetti 2020). The reason for this is likely to be that the question of language is an important one in Montreal; only one flag flies in this neighbourhood. It is the reason why Montreal's Little Portugal is easier to identify.

\subsection{Little Italy and the Italian Community in Montreal}

The Portuguese community may well pinpoint 1953 as the year when the Portuguese migration to Canada began (Moura and Soares 2003). In contrast, the history of the Italian migration to this country is somewhat different and has no fixed date. It began much earlier, at the beginning of the 20th century. In fact, a significant presence of Italians numbering 10,834 was recorded in Canada in the 1901 census. Numbers had increased to 66,769 according to the 1921 Census, and to almost 100,000 individuals in 1931 (Grassi et al. 2014).

In terms of geographical origins, the Italian community is characterised by a prevalence of people coming from the southern regions, the centre and the North-East of Italy. The end of World War II marked a turning point for Italian immigration to Canada, considered the cheapest immigration market to absorb European workers. Between 1947 and 1951, around 50,000 Italians arrived in the country, mainly coming from Friuli (NorthEast), Abruzzo and Molise (Central-South), Campania, Sicily and Calabria (South) (De 
Clementi 2010). According to the 1971 Census, there were 730,830 Italians resident in Canada (Grassi et al. 2014). In 2006, according to Canadian statistics, there were 299,965 individuals declaring themselves Italian and 1,445,330 individuals of Italian origin in the entire country. Italian was the language spoken by 467,905 citizens, representing the third most spoken language of the country after English and French (Statistics Canada 2009). In 2016, this position was already overtaken by the Chinese languages of Mandarin and Cantonese (Statistics Canada 2016). Montreal hosts the second largest Italian community in Canada after Toronto with a total of 147,015 people of Italian ancestry in the city; there are 326,700 in the entire province of Quebec (Statistics Canada 2016).

Montreal represents the first place in which Italians settled in Canada. It was the economic hub of the country and an arrival centre at which a very large concentration of migrants gathered. Between 1900 and 1920, the transition from an Italian 'colony' to an actual 'ethnic enclave' took place - the so-called Little Italy (Ramirez and Del Balso 1980). During the same period, other Little Italies were founded in North America (Harney 1979), e.g., East Harlem and the Lower East Side in New York City, the North End in Boston, Federal Hill in Providence (Rhode Island), Fishermen's Wharf in San Francisco, Oswego (New York), Baltimore, Saint-Louis (Missouri), Philadelphia, Newark (New Jersey), Tampa Bay (Florida), Thunder Bay ${ }^{6}$ and Toronto in Ontario (Gabaccia 2006; Harney and Scarpaci 1981; Mormino 1986; and Immerso 1999).

Unlike the Portuguese community, the Italians settled in different areas of Montreal and built many Little Italies. The first vestiges were in Sainte-Agathe and Saint-Timothée districts, close to the Gay Village today. In this area, in 1905, Madonna del Carmelo (Our Lady of Mount Carmel), the first Italian parish of the city, was founded. A new Italian neighbourhood flourished in the 1910s in the South-West borough of Ville-Émard. During the same period, the new parish of Madonna della Difesa (Our Lady of Defence) was built in 1911 in the borough of Rosemont La Petite-Patrie. This area became home to many Italians who needed more space to build their houses with a real ' iard $^{\prime{ }^{7}}$ (garden, vegetable patch). During the 1920s and 1930s, many grocery shops and restaurants opened in this area, including the large farmers' market of Jean-Talon. In 1936, Casa d'Italia housed in a new Art Deco building became the house of many Italian groups and associations. Although closed during World War II, ${ }^{8}$ Casa d'Italia reopened after the conflict and today hosts different associations and foundations. This institution offers Italian language and cookery classes, lectures on art and culture, exhibitions, and theatrical and musical performances. Today, the two institutions offering Italian classes in around twenty schools (primary and secondary) are PICAI $^{9}$ and CESDA ${ }^{10}$.

After WWII, with new waves of migration from Italy, the community was increasing in size and needed more space. For that reason, starting from the 1950s, many families relocated to less expensive areas in the East and North-East. Two new parishes were built-Madonna della Consolata (Our Lady of the Consolation) near Papineau Avenue in 1960, and Madonna di Pompei (Our Lady of Pompei) in Saint-Michel in 1961. A few years later, in 1967, due to the Expo ${ }^{11}$, Madonna del Carmelo (Our Lady of Mount Carmel) was relocated in the district of Saint-Leonard in response to the need of a large number of Italians moving to the East side of the city. In this area, the Santa Cabrini hospital and the Centro Leonardo da Vinci were created to cater to the needs of the neighbourhood. The new community centre Leonardo da Vinci, created in 2002, accommodated different local

6 Thunder Bay was formerly twin cities formed by the union between Port Arthur and Fort William on Lake Superior in the western part of the province of Ontario.

7 Iarda-from the English 'yard', in Italian 'orto'.

8 Casa d'Italia had to close during the war period and was under the control of the Canadian army. After the war, the building was returned to the community.

9 PICAI-Patronato Italo Canadese per l'Assistenza agli Immigrati: [http:/ / www.picai.org/] (accessed on 19 December 2020).

10 CESDA—Centro Scuola Dante Alighieri: [http://cesdamontreal.com/] (accessed on 19 December 2020).

11 International and Universal Exposition or Expo 67-a major exhibition to showcase the technological and industrial achievements of the host countries. The theme was 'man and his world'. 
associations, federations and clubs needing support to survive. Today, the centre offers Italian classes, culinary workshops and organises different events (sports and culture).

Although this new centre was created because the community wanted an institution in the area, Little Italy in Mile-End is still considered to be the historical centre of the Italian migration in the city (Figure 2). In fact, the transformation from a neighbourhood to a real Little Italy has been a symbolic process. Today, this symbolism is no longer to be interpreted in demographic terms, but rather as the reflex of intercultural relations. This Little Italy is a depository of memory. In the meantime, it has witnessed and experienced a linguistic passage from Little Italy to Petite-Italie (Ramirez 2007). It is, above all, a commercial site where people go to buy Italian products, eat in Italian restaurants or attend religious celebrations during an 'ethnic weekend'. In this neighbourhood, 'Italianness' is offered to all Montrealers.

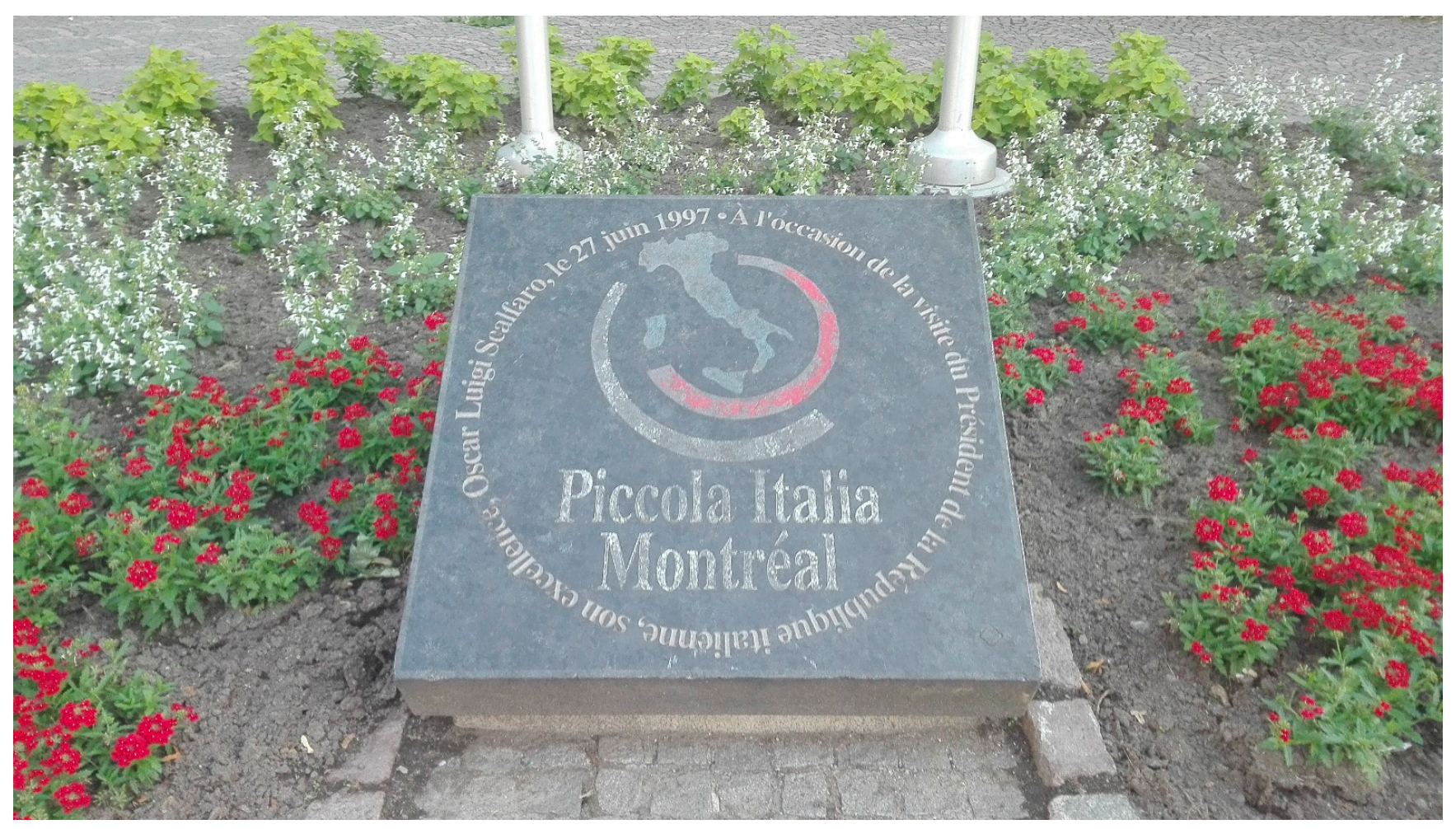

Figure 2. Parc de la Petite-Italie, Saint-Laurent/Saint-Zotique. The park is located next to Little Italy's entrance arches.

\section{Method}

This research paper is based on recent research comparing heritage speakers within the Portuguese and Italian communities, questioning and redefining categories such as heritage speaker (see: Bonfiglio 2010) and heritage identity (see: Adserà and Pytliková 2016; Canagarajah and Silberstein 2012; Norton and Toohey 2011; Kerswill 2006; Esser 2006; Pavlenko and Blackledge 2003), based on a collective identity where a language is associated to a population (see: Errington 2001; Irvine and Gal 2000, among others). This considers the context of study where identity is half-way between linguistic assimilation and multiculturalism (Oakes and Warren 2009). On the one hand, it is a direct continuation of a doctoral study about the Portuguese community (Scetti 2019), and on the other, a post-doctoral research project on the Italian community that began in 2018.

Fieldwork was conducted in Montreal between 2011 and 2019 and employed linguistic ethnographic methods (Creese 2005). Copland and Creese (2015) describe linguistic ethnography as an interpretive approach that studies local and immediate actions of actors from their point of view and considers how such interactions are embedded in wider social contexts and structures (Creese 2010). In our approach, linguistic and ethnographic 
methods are combined in order to understand how important language practices are within a group, as well as to perceive how to build ideologies of in-group inclusion and within the city of Montreal.

The main objective was to undertake an analysis of differences and similarities between both groups, to see whether identifying places plays an important role in the process of integration within each group, in shared spaces of language or dialect practice, both private and public, where ideologies help to build symbolic borders.

Data collection included written questionnaires, non-participant and participant observations and semi-structured interviews. The interviews were mainly audio recorded; observations were recorded and described thanks to narratives. Participants were selected among members from the two communities having Portuguese or Italian origins. The snowball approach was the most convenient and practical way of inclusion of people from both communities. The procedure of selection for the study was organised considering gender, profession, level of study, age and generation. Members were subdivided in generations: first generation (1G) included people who first arrived and settled in Montreal, coming from Portugal and Italy; second generation (2G) included members of both communities born in Canada or who arrived at a very young age from Portugal or Italy; and finally, third and fourth generations ( $3 G$ and $4 G$ ) were represented by members of the communities having grandparents and great grandparents who first came to Canada from the two countries.

The author's linguistic background was essential during data collection and interpretation. Data collection was conducted in both Portuguese and Italian, including French and English in some cases, mainly used with 3G and 4G members. Consequently, transcription and translation were considered in order to analyse language practices and discourses. Nevertheless, in respect to his position as researcher, it was interesting to observe how 'legitimate' the researcher was considered and evaluated by people of both communities while introducing or during the interviews where often interviewees needed to describe and categorise. In Italian, the researcher was often considered to represent 'the standard reference', meaning the one speaking the 'good Italian' or the 'real Italian' because he was born in Italy and had an Italian name and surname. Within the Portuguese community, he was often congratulated for his fluency in the Portuguese language, even to the point that some of them were sometimes convinced he was originally from Portugal, the country where he lived for three years and started his academic career in sociolinguistics.

The interview was the main tool of this research since it helped in assessing people's language uses in different languages or dialects. In total, the entire research employed around one hundred interviews, from 2011 to 2019. In addition, questionnaires helped in evaluating quantitative data and observations enabled to triangulate all these data, mainly bringing to light language practices and divergences with their representations. During observations, participants were followed in their environments, with family members, friends, and at school in their relations with parents, children, other pupils and teachers. Informed consent was obtained from all subjects involved in the study.

Using an ethnographic approach, data are presented in this contribution with a brief presentation of each speaker (name, generation-year of birth, origin-country). Excerpts used to describe the context studied were emended from hesitations and reformulations in order to improve the readability and understanding. A translation in English is offered in the notes.

\section{Results}

In this section, different aspects of multilingual behaviour within these two communities are presented. The aim was to obtain answers to the following questions: 1 . What languages and language practices are members of both communities exposed to, and what are the language practices that emerge from them? 2. What ideologies are created and reinforced by language practice representations? and 3. What are the potential implications 
of these practices and their representations in the identity process of members of each community?

\subsection{Language Practices and Shared Spaces}

Starting from the second generation, children in immigrant communities get exposed to rich multilingual environments (Creese 2005), which allow them to build their own repertoires. It is important to underline a key difference in terms of speakers and their linguistic repertoires between the two communities - the Italian community being much more complex than the Portuguese.

Within the Portuguese community, for instance, observations show the use of English, French or both, together with Portuguese and regional varieties. These varieties were recognisable from the distinctive features such as the dialects of northern Portugal (dialectos setentrionais), mainly from Minho, and insular dialects (dialectos insulares) (Mateus 2005), from the significant immigration from the Azores and Madeira islands.

In carrying out analysis, certain phonetic traits that characterise these dialects were identified. From northern Portugal, for example, analysis shows the disappearance of the opposition between the voiced labiodental fricative consonant /v/ and the voiced bilabial occlusive consonant /b/, which is underlined as an identifying mark of this region, as shown in example (1). In addition, the maintenance of voiceless alveolar fricatives $/ \mathrm{s} /$ and [z] was also identified and the conservation of the diphthong /ow /, as in the following example (2).

(1) Lurdes (1G-1951, Minho-PT): Tinha vinte [bint] e dois anos. ${ }^{12}$

(2) Sílvia (2G-1989, Minho-PT): Tenho outras [owtra $\left.\int\right]$ pessoas conhecidas da família ${ }^{13}$.

Concerning insular dialects, certain features were underlined such as the elevation of the tonic /o/ to [u] and elements of palatalization and depalatalization. The truncation of the final vowel $/ \mathrm{u} /$ written graphically $<\mathrm{o}>$ in normative European Portuguese (EP) was also observed-its realization being more like a [ə] or [i] sound, as in example (3). Another interesting element to highlight, because it was often identified among speakers as a mark of the dialects from the islands, is the centralization of the vowel $/ \mathrm{u} /$ in a [y] sound, as shown in example (4).

(3) Teresa (1G-1956, Madeira-PT): Naquele tempo [tempə] não deixavam ir pa' escola francesa. $^{14}$

(4) Manuel (1G-1957, Azores-PT): Portugal também abriu as portas ao mundo [mynd]. ${ }^{15}$

Morphological features were also observed during analysis. For example, the change in clitics with pronominal verbs, from the enclisis to proclisis position, as in example (5). Analysis shows different instances of the cupola verb between 'ser' (to be, permanent state) and 'estar' (to be, temporary condition) and in particular, the use of existential 'ter' (to have) instead of 'haver' (to have), restricted to writing. Finally, a variety of structures using the expression 'a gente' (we, the people) as a subject with a proclisis position of the clitic were observed, such as in example (6).

(5) Vanessa (3G-1997, Porto-PT): «Eu me chamo Vanessa ». ${ }^{16}$

(6) Mário (2G-1967, Centre-PT): «A gente se junta ». ${ }^{17}$

All these features, in particular those of insular varieties, suffer from stigmatization compared to other practices (Scetti 2017). EP emerges as the norm to use, and the language to learn at school. Within shared spaces of the community, such as the church or the community school, EP is required and has become the lingua franca among members.

(1) I was 22 years old-[vint].

(2) I have more people known from the family-[otra $\left.\int\right]$.

(3) During that period, they did not let people go to the French (Francophone) school-[tempu].

(4) Portugal also, opened its doors to the world-[mundu].

(5) I call myself Vanessa-My name is Vanessa-(chamo-me).

(6) The people (we) SE-CL. Refl get-together.3ps. We get together-(a gente junta-se). 
However, both interview and observation data revealed that it is difficult for the speakers themselves to observe and evaluate linguistic practices in daily life, in particular mixed or hybrid practices, with English, French or both mixed together with Portuguese. These mixed or hybrid practices depend a lot on the linguistic repertoire of each speaker, which are very varied, of the situation where they take place and with whom. Several phenomena were found due to the situation of language contact such as: code-switching, code-mixing, lexical borrowings and interferences (see: Scetti 2019).

For the Italian community, the situation is more complex. Notwithstanding, Standard Italian (SI) is the language of the community, taught and promoted by local institutions, even though it is scarcely the language used, emerging from observations. In addition, its uses occur more commonly in formal contexts within the community's shared spaces (churches and community centres). Diverse languages coexist depending on the context, from private to public spaces thoroughgoing communities' areas and activities. Both interview and observation data acknowledged the use of English, French or both, together with SI and its regional or local varieties (De Blasi 2014). Moreover, the use of other languages was observed, such as Sicilian, Neapolitan or Arbëresh ${ }^{18}$, which their speakers often name 'dialects'.

During data analysis, different regional varieties of Italian were noticed. Distinctive features of dialects of Central, southern Italy and from the North-East were founded. For instance, analysis shows certain phonetic traits that characterize dialects from the centre and the South of Italy, such as tonic vocalisms: from [ə] sound to [3] sound and vice versa, and from [o] sound to [o] sound or vice versa, as in example (7) and (8). Moreover, thanks to analysis, the postnasal lenition of voiceless consonants was pointed out together with the affrication of sibilants in the same position (9), studied as a characteristic of regional Italian from Abruzzo (Avolio 2002, pp. 601-3).

(7) Marilena (2G-1965, Molise-IT): «I primi cinque anni, prima che ho cominciato la scuola [skwola], parlavo solo italiano $» .{ }^{19}$

(8) Pietro (2G-1940, Veneto-IT): « Ho visto il padre sul tetto [teto] cosa voleva fare? ». ${ }^{20}$

(9) Floride (1G-1966, Abruzzo-IT): « Ho detto ai miei nipoti che mantengono [mand'3ngono] la tradizione italiana, il dialetto oppure la lingua italiana anche se non la parlano bene ».21

In addition, some morphological features were observed as well, such as the use of a reinforcing ' $c i$ ' (named attualizzante) as an unstressed third singular person. The use of 'ci' attualizzante is very common and appears twice just in example (10). Later analysis shows the postposition of possessive adjectives (11) and different selections of auxiliaries in syntactic constructions, with both 'essere' (to be) and 'avere' (to have), such as in the following example (12).

(10) Angelina (1G-1957, Sicily-IT): "se io ci parlo l'italiano diciamo, o ci parlo un po' italiano

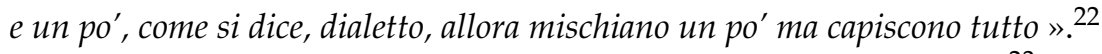

(11) Anna (1G-1949, Campania-IT): «Dove vivono le figlie mie » 23.

(12) Pamela (3G-1998, Sicily/Molise-IT): «I nonni hanno venuto qui nel Canadà » 24.

These features in language practices, in both Portuguese and Italian, reveal the complexity of multilingual behaviour within both communities, in relation to speakers' repertoires, the situation and the context of use. Instead of two or more monolingualisms (García

18 Arbëresh is a language spoken by the Arbëreshë, also known as the Albanians of Italy. It is an Albanian ethnolinguistic group located in southern Italy. They are the descendants of Tosk Albanian refugees, who left the Balkans area between the 14th and the 18th centuries because of the Ottoman invasion.

19 (7) The first five years, before starting school, I used to speak only Italian-[skwola].

20 (8) I have seen the priest on the roof, what was he going to do?-[t3t:o].

21 (9) I told my nephews to maintain the Italian tradition, the dialect or the Italian language, even if they do not speak it properly- [mant'engono].

22 (10) If I speak Italian to them (her daughters) let's say, or a bit of Italian and a bit of, how shall we say, dialect, then they mix it a bit, but they understand everything.

23 (11) Where they live my daughters-(mie figlie).

24 (12) The grandparents have come (arrived) here in Canada-(sono venuti). 
and Lin 2016), it could be examined as a sort of 'multiple multilingualism'. This can be described observing situated linguistic practices where all these languages and dialects find their position. In both cases, it is difficult to put only one flag on each community because varied practices represent communities' multilingual reality. Besides heritage language practices, which include Portuguese, Italian and their regional varieties or other languages, each speaker may add a different language of integration to the context of Montreal, being either English, French or both. This could depend on the time of arrival, area of living, schooling, class and socio-economic status. The choice between the Francophone or the Anglophone education system depends mainly on ancestors' arrival in Canada, before or after the Quiet Revolution (Révolution tranquille)—a period of intense socio-political and socio-cultural change in Quebec during the 1960s and 1970s and the change in linguistic policies $^{25}$. Even the question of gender, socio-economic status and class or ambitions also have to be considered. This period, in fact, had transformed the linguistic policies of integration for immigrants, mainly Bill 101, which oblige children of new immigrants to enrol into the Francophone school system (Mc Andrew 2002).

\subsection{Representations of Language 'Purism'}

The linguistic analysis of language practices was completed by discourse analysis, which carried out varied discourses that circulate within the two communities, having an impact on the process of the construction of linguistic ideologies.

Within the context studied, different phenomena such as code-switching, code-mixing, lexical borrowings and various interferences, were observed and are present daily, as a result of the context of language contact. These practices, mixed or hybrid, are more audible in speakers from second generations and beyond, because of their opportunities to use more than one language. Within a context of language contact, translanguaging is a natural multilingual behaviour depending on the situation, who is involved and how (Blackledge and Creese 2017; García and Wei 2014), as well as truncated multilingualism, depending on varied spaces and diverse functions of communication (Blommaert 2010). This adaptation enabled the observation of a common pattern within certain families in both communities, where parents mainly of $1 \mathrm{G}$ often speak Portuguese or a dialect of Italy and their children answer back in English, French or both. Starting from 2G, the practice of Portuguese or the dialect of Italy often took place during family reunions and English or French became the language of the family. This may depend on the partner and could have influence on the language spoken to children. Moreover, mostly aware of the separate codes which are used in their speech communities, many speakers often separate them in uses. They may over-report their use of socially prestigious languages or varieties and deny their use of socially stigmatised varieties (Milroy and Gordon 2006, pp. 210-11).

Although mixed practices are present daily within the two communities, representations about them are often negative and suffer from bad judgement, and members are often confronted with the normative reference. Carolina (1G-1953, Campania-IT), for example, referring to her arrival in Montreal, understood that the Italian spoken there was different: "qui parlavano l'italianese, un mix con francese e inglese. Non il vero italiano! ${ }^{26}$. Luciana (1G-1952, Latium-IT), who migrated later, in the 1980s, observed how people spoke within the community: «il Franglais parlano, è sbagliato no? $»,{ }^{27}$ asking in an injunctive way a confirmation of her statement from a linguistic point of view. These negative representations support the linguistic ideology of purism of the norm, in which the authentic variety is not the one spoken by older people (Dorian 1994), but the one used within institutions and considered as the norm. Mixing practices are considered to influence the 'good' language negatively, representations of which result from homogenizing

25 Bill 22, «Loi sur la langue officielle (30 July 1974) and Bill 101, « Charte de la langue française » (26 August 1977). The objective of Bill 101 was to make French the language of government and the law, as well as the normal and everyday language of work, instruction, communication, commerce and business. It was also important in terms of restrictions on enrolments in Anglophone schools, mainly for immigrants.

26 Here, they are used to speaking Italianese, a mixture (of Italian) with French and English. Not the real Italian.

27 They speak Franglais, isn't it bad? 
ideologies (Kroskrity 2000; Irvine and Gal 2000; Bauman and Briggs 2000; Blommaert and Verschueren 1998). This ideology of purism (Park and Wee 2017; Kroskrity 1993, 1998) foments the prescriptive nationalist paradigm of the equation: one language, one nation (or community) and one norm. These representations of the 'good' language may then interfere during the process of language transmission from generation to generation and during the process of language learning: for children and adult members who learn the language at an adult age.

Firstly, school is the institution where this paradigm is taken for real. At the Portuguese school Santa Cruz, for example, the EP norm being the one to teach, all teachers are originally from Central Portugal, the area between Coimbra and Lisbon, considered as its cradle. However, observation data from the school reveal teachers' and students' multilingual behaviour. Different levels of tolerance towards classroom code-switching were identified among the teachers, so to influence students' language behaviour in the classroom. Teachers confirmed that pupils are compelled to refrain from using languages other than Portuguese to communicate with other children inside and outside the classroom. Nevertheless, different uses of switches from language to language between students were observed, mainly during breaks. The Portuguese language becomes important as a lingua franca only between children enrolled in the two different schooling systems: the Francophone and the Anglophone. This community's school, open only on Saturdays, has been suffering recently from a decline in the number of enrolments; according to statistics, enrolment began to drop at Santa Cruz in the 2000s (Eusébio 2001). For this school to survive, it needs to promote its activities to families who are still linked to the community or: "abrir-se mais ou recuperar a outras famílias » ${ }^{28}$, as the priest José Maria added.

There is a general discourse between members of Portuguese community about the importance of learning Portuguese-an important language on the international market. Jaime (3G-1995, Minho-PT), for example, underlined its international position: «é $a$ sétima língua mais falada do mundo ». ${ }^{29}$ Lurdes (1G-1951, Minho-PT), a grandmother, understands the chance that her grandchildren have of learning a new international language at home: "é bom saberem falar mais linguas, porque o português também é uma lingua muito falada no mundo $»{ }^{30}$ She believes, as do others, that it is important to speak more languages, and particularly Portuguese, which is widely spoken in the world. This ideology of power and internationalism has put Portuguese on a higher ranking in today's 'market of languages' (Calvet 2002).

Furthermore, in respect to language transmission, ideologies about the use of the 'good' language may influence this process as well. Within the Italian community, for instance, this process is even more complex, because other languages rather than SI are spoken at home. Italian is used sparingly. In fact, throughout the quantitative analysis, it was possible to observe how self-completion written questionnaires constituted a useful alternative tool for collecting quantifiable data on language attitudes, self-reported language behaviour, and mainly language abilities. However, we could observe that Italian descendants were in general more reticent to complete the questionnaire (in Italian), compared to Portuguese descendants. In terms of linguistic policies adopted within families, another important variable to observe was parents' formal education, which can influence language behaviour and language attitudes (Skutnabb-Kangas 2000, p. 500), in particular, if languages were mentioned or not at school and in which way. Heritage language education within the community schools but also education in the Francophone or Anglophone systems can have an important effect on children's language behaviour later (Magnan and Lamarre 2016; Lamarre 2007; Chastenay and Pagé 2007; Gérin-Lajoie 2003), and the maintenance of ethnolinguistic borders (Meintel and Kahn 2005). The following anecdote illustrates this phenomenon: One day, after mass at Madonna della Difesa, a group of women were

28 Open or bring back to other families.

29 It is the seventh most spoken language in the world.

30 It is good to know more languages, because even Portuguese is spoken a lot in the world. 
approached and were asked about language practices at home and within the family. Maria, one of the women (1G, Molise- - IT) answered: « quando muoriamo noi muore la lingua. Con la lingua si va in Sardegna. Qui si parla in America no! » ${ }^{31}$ and then, talking about her nephew, she added: "al nipote chiedono a scuola, ma che lingue parli? E lui, quella della nonna, inglese e francese. E da dove viene la nonna, ci dice la maestra. Dal Molise! » ${ }^{32}$, making all her friends burst into laughter. The example of what Maria said shows the importance of transmitting the heritage language at home and confirms how important dialects still are within Italian families today, more than the Italian language. Luciano (2G-1964, Sicily-IT), for example, explains how hard it was for him to study Italian: «A casa coi miei genitori parlo solo siciliano. L'italiano l'ho imparato, i miei genitori mi hanno forzato, ero piccolo, per tre, quattro anni alla PICAI il sabato mattina. L'ho poi studiato alla scuola secondaria e a livello collegiale ». Besides, he was forced by his father to attend the Italian school on Saturdays, and he recognised how important it was to make a decision about his daughter too. Today, in speaking about her (who cannot speak Italian or Sicilian), he regrets not being like his father. « $\grave{E}$ colpa mia, nostra, non abbiamo fatto come mio padre ", ${ }^{33}$, he adds, indicating how important decisions are in both language transmission and learning. As for the school, observation data show that even at home, if parents would typically initiate conversation with their children and respond to them in their heritage language, children would use English, French or both. This was observed also within parents of $2 \mathrm{G}$ who decided to use their heritage language at home. Nevertheless, in comparison to teachers, they were generally more tolerant to the use of these languages by their children.

In conclusion, the ideologies of 'purism' of the 'good' language and of power have an influence on families' language policies in terms of language transmission, choice for children's enrolment at the community's school on Saturdays and of language behaviours, having consequences on the process of identity.

\subsection{From Essentialised to Dynamic Identity}

The process of identity is another question revealed through the comparison between the two groups, mainly considering potential implications of language practices, language behaviour and language representations during this process. The main point is to see if between members of the communities, language is still an identity marker.

Language practices and multilingual behaviour can be a cause for developing new identities within the groups. The choice of language, however, may have important implications for both language and identity learning (Norton 2013). The process of identity is then seen as a process of learning how to behave oneself and within a community. Defining the identity of a group remains a way of drawing limits, or boundaries with those who do not belong to the group (Tabouret-Keller 1997), and who may be excluded because of their practices. Language practices and multilingual behaviour may be evaluated and judged by other members in order to be identified as members themselves.

Within the Portuguese and Italian communities, the importance of promoting their own languages in a context of multilingualism such as Montreal was very apparent. Certain members and certain institutions, such as community schools, associations and clubs, for instance, like to promote discourses in favour of a 'good' and pure language practice or to overvalue the power of those languages. These discourses are based on linguistic ideologies as the situated, partial, and interested character of conceptions and uses of language (Errington 2001, p. 110); for example, the promotion of Portuguese as being an international language today (Scetti 2020). The agency of those institutions and community members in the process of the creation of linguistic ideologies is fundamental, in what concerns the positioning of these representations of language practices as a collective marker

31 When we die, the language will die. With the language we can go to Sardinia (saying). Here, we are talking about America.

32 They ask my nephew at school, "Which languages do you speak? And he (answers), "My grandma's, English and French". "And where is your grandmother from", says the teacher. "From Molise!"

33 At home with my parents, I speak Sicilian. I have learnt Italian, my parents forced me when I was a child of three, four years at PICAI (school), on Saturday mornings. I learnt it later at secondary school and at college. It is my, our (him and his wife's), fault. We have not done like my father. 
of identity for the group. Community members are then forced to face an 'essentialised' identity where markers have been already fixed. One has to deal with a kind of double relationship between a chosen identity, and one that has been imposed on him/her-an assigned identity (Scetti 2019).

Analysis of observation and interview data demonstrated how identities may consist in both an identity of inclusion within the group (community and also regional and town of origin), as well as within the city of Montreal. Data showed how stereotypical attitudes are still present within community members, such as an auto-evaluation of language practices in terms of purism and fluency. Language practices are a marker of identity, and speaking in a 'good' way may be synonymous with being well considered or considering oneself as part of the group. Florbela (2G-1970, Centre, PT), for instance, after a one-hour interview, yet again, auto-evaluated herself in the negative way she has been told and judged since her childhood: «o meu é que tá tatata ... ». ${ }^{34}$ Vittorio (1G-1953, Calabria-IT), as well, before even starting to talk, put forward: «sono analfabeto, una volta in dialetto, italiano, una volta francese, inglese $»^{35}$, justifying his language practises despite the fact that he was also giving a complete view of his multilingual behaviour day-to-day. These reactions and evaluations of language practices were common during interviews, and speakers often outlined their practices even before starting the recording. The author decided to speak Italian or Portuguese according to the interviewees. Nonetheless, in a total of one hundred interviews, only two interviewees chose French and one English within the Portuguese community, and six chose English within the Italian community.

Nevertheless, in the city of Montreal, where people are highly multilingual, it is difficult to be identified with only one language and one practice. This context helped in maintaining heritage languages as well as developing new identities. First of all, both the Portuguese and the Italian communities, even if more numerous in Toronto than in Montreal, since the 1980s, were more inclined to maintain their languages in Montreal than in the English-only context of Toronto (Da Rosa and Poulin 1986). This tendency seems to recur even nowadays. Elizabeth (2G-1980, Azores-PT), for example, referred to how Portuguese is less present at home than for her relatives living in Toronto and in the United States: «é pena se perder e vê, a gente vê muito. Mais nas comunidades como em Toronto e nos Estados Unidos, por exemplo os meus primos nenhum fala portuguê e é pena porque eles sentem-se português, tem as bandeiras de Portugal nos quartos e essa coisa toda mas não falam a lingua, e voltando a Portugal não sabendo a língua, perde-se muito $»{ }^{36}$ These observations are very common, even within the Italian community. About Italian communities in the United States and the practice of Italian, for instance, Daniela (3G-1984, Latium-IT), while travelling or with her relatives there, observed in a very critical way that: "gli Americani hanno solo il nome, ma non parlano! ", ${ }^{37}$ focusing on other markers of identity than language practices.

The danger of a high linguistic diversity in shared spaces is to create a conflict in terms of choices between generations. Multilingual behaviours and mixed practices among speakers from $2 \mathrm{G}$ and beyond can be seen as resisting norms of $1 \mathrm{G}$ speakers-in which mixed practices where less present. This may challenge expectations about identity and ethnicity, as if to indicate that identities are not related to ethnicity (Mooney and Evans 2015). The transition from one generation to another represents an ideal point in time to investigate differences in language behaviour towards the various languages employed inside the two communities. Thanks to data collection, it was interesting to understand how language practice is perceived as a marker of identity, and how this practice is evaluated within the group and by whom. The choice to speak a language or more languages then

34 Mine (the Portuguese language) is so and so.

35 I am illiterate (analfabeta), once (I speak) in dialect, Italian, once in French, English.

36 It's a pity to lose (the Portuguese language) and we can see; we can see this a lot. More in communities like Toronto or the United States, for example, my cousins do not speak Portuguese, and this is a pity because they feel Portuguese. They have a flag of Portugal in their rooms and all these things, but they do not speak the language, and when going back to Portugal without knowing the language, one misses out on a lot (of things).

37 Italian-Americans have only their (Italian) name but they do not speak (the language). 
becomes an 'act of identity' (Le Page and Tabouret-Keller 1985), in a way that speakers discursively expose their personal identity, their group affiliation, in a certain context and situation. Elijah (3G-2000, Minho/Centre-PT), for example, exposed his identity through language practices: "sinto-me mais português que inglês », in which the practice in English has become the equivalent of being Canadian Anglophone. Later, he added information about his relation to his grandparents and the importance they had in language transmission: "porque eu falei muito com a minha avó e o meu avô e a minha primeira língua era português ». ${ }^{38}$

In conclusion, the 'essentialised' identity, often defended by 1G members, has evolved into dynamic identities where language practices are varied and in contrast with the sole idea of one language equal to one community. However, as shown in the example above, a strong link between language practices and identity exists. Somehow, heritage languages help in building a bridge between the older and younger generations within the communities.

\section{Conclusions}

The focus and analysis of the research brought to light how multilingual behaviour is intricately linked to the context in which it appears. In the city of Montreal, where multilingual practice is well perceived, language practices in languages other than English or French are present and survive. Language behaviour is influenced by a multitude of factors, both socio-psychological and contextual in nature. This research attempts to help gain an understanding of the motivations of transmission and education in both the Portuguese and Italian languages within the two groups, underlying why these actions are important for the identity of each community. These language behaviours are, therefore, faced with an extremely complex network of factors which all contribute to a speaker's language production to varying degrees. Moreover, these behaviours are very common in the context of migration and transcend physical, social and symbolic borders within shared spaces (Watt and Llamas 2017; Auer et al. 2013).

The focus on language practices, language behaviours in context and the speakers' personal identities enables the research to observe the reasons for the use of more than one language in a single interaction. However, due to the automaticity of convergence, it can be extremely difficult to reveal with certainty whether a speaker is conscious on how he/she adjusted his/her language use to that of his/her interlocutor. Moreover, this study sought to explore how language practices are strictly related to identity. Thus, the emergence of new identities today among descendants of both migrations may be attributed largely to the flexible, multilingual context within the group.

In carrying out the quantitative analysis, due to our choice to privilege interviews over observations, phenomena of highly multilingual natures were not consistently recorded and transcribed. In spite of this, it was interesting to explore the significant efforts parents and grandparents made to ensure intergenerational transmission of their heritage languages in their homes. The situation is very similar in both communities, where the family is the first place where heritage languages are present. Within the Portuguese community, the Portuguese language is dominant in shared spaces. By contrast, the Italian language has to share its position with dialects or mostly English. Standard Italian cohabitates with different languages and regional or local varieties. During ethnography, we observed how regional spaces such as associations and clubs were also important in the past, i.e., Casa del Veneto (for Venetians) Fogolar furlan (for Friulians), Casa dos Açores (Azoreans) among others. However, the propensity today is to converge into a common 'national space'-the Centro Leonardo da Vinci is a good example for the Italian community. Many regional associations merged into bigger groups or organisations and rented a room there. Observation data showed how non-standard varieties and dialects were mainly present in day-to-day practices within

38 I feel more Portuguese than English (Anglophone). Because I spoke a lot (Portuguese) with my grandmother and grandfather and my first language was Portuguese. 
members of the two communities. However, a general negative discourse about how Italian is 'badly' spoken today between members is influencing descendants' behaviour in this language. Filippe (2G-1966, Campania-IT), for example, referring to the Italian language, affirmed: "gli italiani lo parlano storto, non il vero italiano ». ${ }^{39}$ Laura (3G-1990, Latium-IT), explained how Italian descendants speak Italian with the same peculiar accent: «A Saint-Léonard e a Rivière-des-Prairies tutti parlano alla stessa maniera ».40

Concerning language practices in general, observations showed how these practices are flexible due to the dynamicity in speakers' repertories. Data analysis revealed different characteristics of both varieties in Portuguese and Italian, as well as translanguaging and the phenomenon of the situation of language contact. All these mixed or hybrid practices, generally attributed to migrants or their descendants (Blommaert 2010), suffer from negative representations because of their influence on language 'purism'. The 'good' language is still the language upheld within these two groups. It seems as though only one flag is towering over both communities, even if, in terms of practices, both languages are less present and sometimes share spaces with English, French or both. In conclusion, even if multilingual behaviours are present within both communities, a question of authenticity and purism of a language is often defended by members as the 'good' one for the future of the community. Within the Portuguese and the Italian communities, over and above the desire to be Montrealers, it is also essential to be Portuguese or Italian in Montreal.

Funding: This research received no external funding.

Institutional Review Board Statement: The study was conducted according to the guidelines of the Declaration of Helsinki, and approved by the Institutional Review Board (or Ethics Committee) of Dipralang, Université Paul-Valéry Montpellier 3, Montpellier (27 February 2021).

Informed Consent Statement: Informed consent was obtained from all subjects involved in the study.

Data Availability Statement: Data available in a publicly accessible repository that does not issue DOIs.

Conflicts of Interest: The author declares no conflict of interest.

\section{References}

Adserà, Alícia, and Mariola Pytliková. 2016. Language and migration. In The Palgrave Handbook of Economics and Language. London: Palgrave Macmillan, pp. 342-72.

Almeida, Erika. 2014. La citoyenneté au-delà des frontières nationales: La politique étrangère brésilienne et les Brésiliens au Québec. Revue Interdisciplinaire de Travaux sur les Amériques (RITA). Available online: http:/ / www.revue-rita.com/dossier7/la-citoyenneteau-dela-des-frontieres-nationales-la-politique-etrangere-bresilienne-et-les-bresiliens-au-quebec.html (accessed on 19 December 2020).

Anctil, Pierre. 1984. Double majorité et multiplicité interculturelle à Montréal. Recherches Sociographiques 3: 441-56. [CrossRef]

Auer, Peter, Martin Hilpert, Anja Stukenbrock, and Benedikt Szmrecsanyi. 2013. Space in Language and Linguistics: Geographical, Interactional, and Cognitive Perspectives. Berlin: De Gruyter.

Avolio, Francesco. 2002. L'Abruzzo. In Dialetti italiani. Storia, struttura, uso. Edited by Manlio Cortelazzo, Carla Marcato, Nicola De Blasi and Gianrenzo P. Clivio. Torino: UTET, pp. 568-607.

Bauman, Richard, and Charles L. Briggs. 2000. Language philosophy as language ideology: John Locke and Johann Gottfried Herder. In Regimes of Language: Ideologies, Polities, and Identities. Edited by Paul V. Kroskrity. Santa Fe: School of American Research Press, pp. 139-204.

Blackledge, Adrian, and Angela Creese. 2017. Translanguaging and the body. International Journal of Multilingualism 14: 250-68. [CrossRef]

Blommaert, Jan. 2010. The Sociolinguistics of Globalization. Cambridge: Cambridge University Press.

Blommaert, Jan, and Jef Verschueren. 1998. The Role of Language in European Nationalist Ideologies. In Language Ideologies: Practice and Theory. Edited by Bambi B. Schieffelin, Kathryn Woolard and Paul V. Kroskrity. New York: Oxford University Press, pp. 189-210.

Bonfiglio, Thomas P. 2010. Mother Tongues and Nations: The Invention of the Native Speaker. New York: De Gruyter Mouton.

Calvet, Louis-Jean. 2002. Le marché aux langues: Les effets linguistiques de la mondialisation. Paris: Plon.

39 Italians speak it crooked (wrong), not the real Italian (language).

40 In Saint-Leonard and Rivière-des-Prairies, they all speak in the same way. 
Canagarajah, Suresh, and Sandra Silberstein. 2012. Diaspora identities and language. Journal of Language, Identity, E Education 2: 81-84.

Chastenay, Marie-Hélène, and Michel Pagé. 2007. Le rapport à la citoyenneté et à la diversité chez les jeunes collégiens québécois: Comment se distingue la deuxième génération d'origine immigrée? In La $2^{e}$ génération issue de l'immigration: Une comparaison France-Québec. Edited by Maryse Potvin, Paul Eid and Nancy Venel. Outremont: Athéna, pp. 239-56.

Copland, Fiona, and Angela Creese. 2015. Linguistic Ethnography: Collecting, Analysing and Presenting Data. London: Sage Publications. Creese, Angela. 2005. Teacher Collaboration and Talk in Multilingual Classrooms. Clevedon: Multilingual Matters.

Creese, Angela. 2010. Linguistic Ethnography. In Research Methods in Linguistics. Edited by Lia Litosseliti. London and New York: Continuum, pp. 138-54.

Da Rosa, Victor Manuel Pereira, and Richard Poulin. 1986. Espaces ethniques et question linguistique au Québec: À propos des communautés italienne et portugaise. Canadian Ethnic Studies/Études ethniques au Canada 18: 143-50.

Das, Sonia. 2008. The Talk of Tamils in Multilingual Montreal: A Study of Intersecting Language Ideologies in Nationalist Quebec. Studies in Ethnicity and Nationalism 8: 230-47. [CrossRef]

De Blasi, Nicola. 2014. Geografia e storia dell'italiano regionale. Bologna: Il Mulino.

De Clementi, Andreina. 2010. Il prezzo della ricostruzione. L'emigrazione italiana nel secondo dopoguerra. Roma and Bari: Laterza.

Dorian, Nancy Currier. 1994. Purism vs. compromise in language revitalization and language revival. Language in Society 23: 479-94. [CrossRef]

Errington, Joseph. 2001. Ideology. In Key Terms in Language and Culture. Edited by Alessandro Duranti. Malden: Blackwell, pp. 110-12.

Esser, Hartmut. 2006. Migration, Language and Integration. Berlin: WZB.

Eusébio, Joaquim. 2001. Falando Português em Montréal. Montreal: Quebec World.

Gabaccia, Donna Rae. 2006. Global Geography of «Little Italy». Italian Neighborhoods in Comparative Perspective. Modern Italy 11: 9-24. [CrossRef]

García, Ofelia, and Angel Lin. 2016. Translanguaging in bilingual education. In Bilingual Education (Vol. 5), Encyclopedia of Language and Education. Edited by Ofelia García, Angel Lin and Stephen May. Cham: Springer, pp. 117-30.

García, Ofelia, and Li Wei. 2014. Translanguaging: Language, Bilingualism, and Education. New York: Palgrave MacMillan.

Gérin-Lajoie, Diane. 2003. Parcours identitaires de jeunes francophones en milieu minoritaire. Sudbury: Prise de parole.

Germain, Annick. 1999. Les quartiers multiethniques montréalais: Une lecture urbaine. Recherches Sociographiques 40: 9-32. [CrossRef]

Grassi, Tiziana, Enzo Caffarelli, and Mina Cappussi. 2014. Dizionario enciclopedico delle migrazioni italiane nel mondo. Roma: SER.

Harney, Robert F. 1979. Men Without Women: Italian Migrants in Canada, 1885-930. Canadian Ethnic Studies 11: $29-47$.

Harney, Robert F., and J. Vincenza Scarpaci. 1981. Little Italies in North America. Toronto: The Multicultural History Society of Ontario.

Heller, Monica. 2007. «Langue», «communauté» et «identité»: Le discours expert et la question du français au Canada. Anthropologie et Societes 31: 39-54, (Numéro thématique « L'appropriation langagière »). [CrossRef]

Immerso, Michael. 1999. Newark's Little Italy: The Vanished First Ward. New Brunswick: Rutgers University Press.

Irvine, Judith T., and Susan Gal. 2000. «Language ideology and linguistic differentiation». In Regimes of Language: Ideologies, Polities, and Identities. Edited by Paul V. Kroskrity. Santa Fe: School of American Research Press, pp. 35-84.

Kerswill, Paul. 2006. Migration and Language. In Sociolinguistics/Soziolinguistik: An International Handbook of the Science of Language and Society, 2nd ed. Edited by Klaus Mattheier, Ulrich Ammon and Peter Trudgill. Berlin: De Gruyter, vol. 3, pp. $2271-85$.

Kroskrity, Paul V. 1993. Language, History, and Identity: Ethnolinguistic Studies of the Arizona Tewa. Tucson: University of Arizona Press.

Kroskrity, Paul V. 1998. Arizona Tewa Kiva Speech as a Manifestation of Linguistic Ideology. In Language Ideologies: Practice and Theory. Edited by Bambi B. Schieffelin, Kathryn A. Woolard and Paul V. Kroskrity. New York: Oxford University Press, pp. $103-22$.

Kroskrity, Paul. V. 2000. Regimes of Language. Ideologies, Polities and Identities. Santa Fe: School of American Research Press.

Lamarre, Patricia. 2007. Anglo-Quebec today: Looking at community and schooling issues. International Journal of the Sociology of Language 185: 109-32. [CrossRef]

Le Page, Robert B., and Andrée Tabouret-Keller. 1985. Acts of Identity: Creole-Based Approaches to Language and Ethnicity. Cambridge: Cambridge University Press.

Linteau, Paul-André. 2000. Histoire de Montréal depuis la Confédération, 2nd ed. Montreal: Éditions du Boréal.

Magnan, Marie-Odile, and Patricia Lamarre. 2016. Diversité, frontières ethnolinguistiques et éducation au Québec et au Canada/Diversity, Ethnolinguistic Boundaries and Education in Québec and Canada. Minorités linguistiques et société/Linguistic Minorities and Society 7: 4-17. [CrossRef]

Mateus, Maria Helena M. 2005. A mudança da língua no tempo e no espaço. In A Lingua Portuguesa em Mudança. Edited by Maria Helena M. Mateus and Fernanda Bacelar do Nascimento. Lisboa: Editorial Caminho, pp. 13-30.

Mc Andrew, Marie. 2002. La loi 101 en milieu scolaire: Impacts et résultats. Revue d'aménagement linguistique Automne, 69-83.

Meintel, Deirdre, and Emmanuel Kahn. 2005. De génération en génération: Identités et projets identitaires de Montréalais de la "deuxième génération". Ethnologies 27: 131-63. [CrossRef]

Milroy, Lesley, and Matthew Gordon. 2006. Sociolinguistics: Method and Interpretation. Oxford: Blackwell Publishing.

Mooney, Annabelle, and Betsy Evans. 2015. Language, Society and Power: An Introduction. London and New York: Routledge.

Mormino, Gary R. 1986. Immigrants on the Hill: Italian-Americans in St. Louis, 1882-982. Urbana and Chicago: University of Illinois Press.

Moura, Manuel de Almeida, and Imitério Soares. 2003. Pionniers. L'avant-garde de l'Immigration Portugaise, Canada 1953. Montréal: Direcção Geral dos Assuntos Consulares e Comunidades Portuguesas. 
Norton, Bonny. 2013. Identity and Language Learning: Extending the Conversation, 2nd ed. Bristol: Multilingual Matters.

Norton, Bonny, and Kelleen Toohey. 2011. Identity, language learning, and social change. Language Teaching 44: 412-46. [CrossRef]

Oakes, Leigh, and Jane Warren. 2009. Langue, citoyenneté et identité au Québec. Quebec City: Presses de l'Université Laval.

Park, Seong Man, and Mela Sarkar. 2007. Parents' attitudes toward heritage language maintenance for their children and their efforts to help their children maintain the heritage language: A case study of Korean-Canadian immigrants. Language, Culture and Curriculum 20: 223-35. [CrossRef]

Park, Joseph Sung-Yul, and Lionel Wee. 2017. Nation-state, transnationalism, and language. In The Routledge Handbook on Migration and Language. Edited by Suresh Canagarajah. New York: Routledge, pp. 47-62.

Pavlenko, Aneta, and Adrian Blackledge. 2003. Negotiation of Identities in Multilingual Contexts. Clevedon: Multilingual Matters.

Pretelli, Matteo. 2011. L'emigrazione italiana negli Stati Uniti. Bologna: Il Mulino.

Ramirez, Bruno. 2007. Quartiers italiens et Petites Italies dans les métropoles canadiennes. In Les Petites Italies dans le monde. Edited by Marie-Claude Blanc-Chaléard, Antonio Bechelloni, Bénédicte Deschamps, Michel Dreyfus and Éric Vial. Rennes: Presses universitaires de Rennes, pp. 73-87.

Ramirez, Bruno, and Michael Del Balso. 1980. The Italians of Montreal: From Sojourning to Settlement, 1900-21. Montreal: Éditions du Courant.

Sarkar, Mela, and Bronwen Low. 2012. Multilingualism and popular culture. In Handbook of Multilingualism. Edited by Marilyn Martin-Jones, Adrian Blackledge and Angela Creese. London: Routledge, pp. 403-18.

Scetti, Fabio. 2017. Variation dialectale du portugais parlé au sein de la communauté de Montréal. Géolinguistique 17: 151-75. [CrossRef]

Scetti, Fabio. 2019. La communauté portugaise de Montréal: Langue et identité. Quebec: Presses de l'Université Laval.

Scetti, Fabio. 2020. Le portugais est la 7e langue la plus utilisée au monde ! Promotion de la langue portugaise dans deux communautés portugaises en Amérique du Nord. Langage et Société 170: 87-108. [CrossRef]

Skutnabb-Kangas, Tove. 2000. Linguistic Genocide in Education-Or Worldwide Diversity and Human Rights. Mahwah: Lawrence Erlbaum Associates.

Statistics Canada. 2009. Census of Canada (2006): Citizenship, Immigration, Birthplace, Generation Status, Ethnic Origin, Visible Minorities, and Aboriginal Peoples. Ottawa: Industry Canada.

Statistics Canada. 2016. Census of Canada (2011): Immigration and Ethnocultural Diversity. Ottawa: Industry Canada.

Tabouret-Keller, Andrée. 1997. Le nom des langues I-Les enjeux de la nomination des langues. Collection BCILL 95. Louvain-La-Neuve: Peeters.

Teixeira, Carlos, and Victor M. P. Da Rosa. 2009. The Portuguese in Canada: Diasporic Challenges and Adjustment, 2nd ed. Toronto: University of Toronto Press.

Watt, Dominic, and Carmen Llamas. 2017. Identifying Places: The Role of Borders. In Language and a Sense of Place: Studies in Language and Region. Edited by Chris Montgomery and Emma Moore. Cambridge: Cambridge University Press, pp. 191-214.

Zucchi, John. 2007. A history of Ethnic Enclaves in Canada. Ottawa: Canadian Historical Association, vol. 9. 